\title{
Elderly Nutrition Status In Caringin Health Center Posbindu
}

\author{
Citra Windani Mambang Sari, Clara Dwi Amri, Titin Sutini \\ Fakultas Keperawatan Universitas Padjadjaran \\ Email : citra.windani@unpad.ac.id
}

\begin{abstract}
Elderly is one of the most vulnerable groups to nutritional problems. Elderly people should maintain nutritional status at optimum conditions, so they can help their physical condition in the process in adjusting to the changes they experience. The purpose of this study was to determine the description of the nutritional status of the elderly at Posbindu Caringin Health Center. The research method was descriptive using a cross-sectional approach. The number of respondents was 125 people that chosen using purposive sampling technique. Data collection using a Mini Nutrition Assessment questionnaire and analyzed using percentage and frequency distribution. The study found that the elderly had normal nutritional status $(68.0 \%)$, the risk of malnutrition $(27.2 \%)$, and malnutrition $(4.8 \%)$. The conclusions in this study are the nutritional status of the elderly in Posbindu Pusingin Caringin, most of the elderly have normal nutrition. Community nurses are expected to be able to use this information in determining appropriate interventions and prevention related to the nutrition problems of the elderly.
\end{abstract}

Keywords: Elderly people, mini nutrition assesment, nutrition status. 
Citra Windani Mambang Sari: Elderly Nutrition Status In Caringin Health Center Posbindu

\section{Introduction}

The elderly population is expected to continue to increase globally throughout the world. In 2012, the percentage of the elderly in Indonesia reached $7 \%$ and will continue to increase to $11.34 \%$ in 2020 . Based on the World Health Organization (WHO), in 2050 Indonesia is predicted to be included in the top 10 countries with the number of elderly reaching 10 million (WHO, 2013).

The increasing number of elderly people can cause a variety of complex problems for the elderly, family, and the community, including biological, mental, physical or socio-economic aspects. One of the problems for the elderly can affect the food intake of the elderly, which will affect the nutritional status of the elderly (Ministry of Health, 2016). The elderly are among the groups most vulnerable to nutritional problems. Nutritional problems that occur in the elderly can be in the form of malnutrition (malnutrition) and overnutrition (obesity). The prevalence of malnutrition tends to increase in the elderly group at 10$50 \%$ (Tamher \& Noorkasiani, 2009). In Indonesia, the incidence of malnutrition in the elderly was around $31 \%$ and only $1.8 \%$ for overnutrition problems (Ministry of Health, 2005). Research in Semarang stated that around $17.2 \%$ of the elderly were in poor nutritional status, normal nutritional status was $46.6 \%$, and overnutrition was $36.2 \%$ (Sari, 2013). Research at Sijunjung conducted by Munawirah, Masrul, and Martini (2014) stated that respondents $22.8 \%$ had good nutrition, $77.2 \%$ had malnutrition (risk of malnutrition and malnutrition). Nutrition problems in the elderly will increase the risk of disease, increase the severity and complications of the disease, cognitive impairment, and poor quality of life (Lee \& Tsai, 2012).

Data from the West Java Health Office (2016) showed that the highest number of elderly in the province of West Java was Bandung City, and the Public Health Center in Bandung which has the most elderly is Puskesmas Caringin, which is 12,029. From the information obtained, the assessment of the nutritional status of the elderly in Posbindu was only by measuring the Body Mass Index. The results of the preliminary study at the Puskesmas Caringin which had normal nutritional status were $49 \%$, overnutrition $36 \%$, malnutrition $15 \%$. So the nutritional status of the elderly at the Caringin Health Center was found that it had not reached half and there were still elderly people who experienced over nutrition and undernutrition.

A preliminary study conducted on 10 elderly in Caringin Health Center, based on the results of interviews obtained 5 people said that the food was provided by their children, 2 people said that the food was cooked by their partners, and 3 people said that the food was cooked. Elderly people whose food is provided by their children say that they often experience a lack of appetite because this food is not according to their taste. In this case, the nurse acts as the geriatric care source. The role and function of nurses are to provide direct nursing care (caregiver provider), including nutrition issues of elderly patients.

The purpose of the study was to determine the description of the nutritional status of the elderly at Posbindu Caringin Health Center. This research is expected to help nurses in preventing nutritional problems and making nursing care regarding nutrition issues in the elderly in the community.

\section{Research Method}

The design of this research was a descriptive quantitative study using a cross-sectional approach. The population in this study was elderly over 60 years old who participated in the Posbindu activity at the Caringin Bandung Health Center which was based on 182 data. Caringin Health Center is the Puskesmas with the most elderly in the city of Bandung. The sampling technique used in the study was purposive sampling with inclusion criteria, namely the elderly were able to communicate in two directions and did not have cognitive damage. The number of samples obtained in accordance with the inclusion criteria in this study was 125 respondents.

The researcher has tested the validity of the MNA questionnaire on 20 elderly people and obtained the results $(0.456-0.705)$ which are worth more than $\mathrm{r}$ table $(0.44)$, 
Citra Windani Mambang Sari: Elderly Nutrition Status In Caringin Health Center Posbindu

while the results of the reliability test of the MNA questionnaire are 0.74 . This shows that the Cronbach alpha coefficient $p$ in this questionnaire is greater than the minimum Cronbach alpha coefficient of 0.7 then the questionnaire is reliable.

The data collection instrument used in this study was a form of the questionnaire from The Mini Nutritional Assessment consisting of 2 parts, namely screening, and assessment. As many as 6 questions at the beginning are screening or what is called the short form MNA. After getting the screening results, the total value is added up, the total value of the short form MNA is 14 if the score is more than 12 normal, $\leq 11$ may be malnutrition. If the elderly are identified as enabling malnutrition (score $\leq 11$ ) then the assessment of the elderly is continued by asking 12 questions for the elderly. Then add up the value of the assessment results and the results of the screening.

The research has applied the ethical principles including autonomy, respect, beneficence, and justice. Researchers have obtained permission from the Research Ethics Commission number 176 / UN6.KEP
/ EC / 2018. Data collection was collected from respondents who came to Posbindu, the respondents carried out activities at Posbindu posts first such as checking body weight, height, and checking blood pressure. After that, the researcher introduces the identity of the researcher to the respondent and conducts informed consent. The MNA questionnaire was assessed by conducting interviews with respondents. If the researcher cannot participate in the posbindu activity, the researcher takes the data door to door to the elderly house that follows the Posbindu. The data were analyzed by the researcher using percentage analysis and frequency distribution.

\section{Research Results}

Based on table 2, it can be seen that respondents aged 75-90 years had a distribution with malnutrition nutritional status $27(8.0 \%)$, female sex with malnutrition nutritional status as many as 5 people $(7.3 \%)$, elderly who had previously attended as many as 4 people ( $3.9 \%)$ with nutritional status malnutrition, living with a family of 5 people

Tabel 1. Distribution of Nutrition Status $(n=125)$

\begin{tabular}{lcc}
\hline \multicolumn{1}{c}{ Variable } & Frequency (f) & Persentation (\%) \\
\hline Nutritional Status & & \\
Normal & 85 & 68 \\
Malnutritional Risk & 34 & 27.2 \\
Malnutritional & 6 & 4.8 \\
\hline
\end{tabular}

Table 2 Sample Nutrition Status Based on Characteristics and Nutritional Status $(n=125)$

\begin{tabular}{|c|c|c|c|c|c|c|c|}
\hline \multirow[t]{3}{*}{ Variable } & \multicolumn{6}{|c|}{ Nutritional Status } & \multirow[t]{2}{*}{ Total } \\
\hline & \multicolumn{2}{|c|}{ Normal } & \multicolumn{2}{|c|}{$\begin{array}{l}\text { Malnutritional } \\
\text { risk }\end{array}$} & \multicolumn{2}{|c|}{ Malnutritional } & \\
\hline & f & $\%$ & f & $\%$ & f & $\%$ & \\
\hline \multicolumn{8}{|l|}{ Age } \\
\hline Elderly (60-74) & 79 & 72.4 & 27 & 24.8 & 3 & 2.8 & 109 \\
\hline Old (75-90) & 6 & 10.9 & 7 & 4.4 & 3 & 8 & 16 \\
\hline \multicolumn{8}{|l|}{ Gender } \\
\hline Male & 44 & 78.6 & 11 & 19.6 & 1 & 1.8 & 56 \\
\hline Female & 41 & 59.4 & 23 & 33.3 & 5 & 7.3 & 69 \\
\hline $\begin{array}{l}\text { Educational } \\
\text { Background }\end{array}$ & & & & & & & \\
\hline
\end{tabular}


Citra Windani Mambang Sari: Elderly Nutrition Status In Caringin Health Center Posbindu

\begin{tabular}{lccccccc}
\hline No & 11 & 50 & 9 & 40.9 & 2 & 0.9 & 22 \\
Yes & 74 & 71.8 & 25 & 24.2 & 4 & 3.9 & 103 \\
Maritas Status & & & & & & & \\
Married & 61 & 72.6 & 20 & 23.8 & 3 & 3.6 & 84 \\
Widow & 24 & 58.5 & 14 & 34.1 & 3 & 7.4 & 41 \\
Live with & & & & & & & \\
Live alone or with a partner & 39 & 78 & 10 & 20 & 1 & 2 & 50 \\
Live with Family & 46 & 61.3 & 24 & 32 & 5 & 6.2 & 75 \\
Job Status & & & & & & & \\
Does not Work & 54 & 66.7 & 22 & 27.2 & 5 & 6.1 & 81 \\
Work & 31 & 70.5 & 12 & 27.3 & 1 & 2.2 & 44 \\
Disease History & & & & & & & \\
No & 33 & 70.2 & 13 & 27.7 & 1 & 2.1 & 47 \\
Yes & 52 & 66.7 & 21 & 26.9 & 5 & 6.4 & 78 \\
Number of Teeth & & & & & & & \\
Still Complete & 7 & 87.5 & 1 & 12.5 & 0 & 0 & 8 \\
It is Incomplete & 71 & 65.7 & 32 & 29.6 & 5 & 4.7 & 108 \\
Use Dentures & 7 & 77.8 & 1 & 11.1 & 1 & 11.1 & 9 \\
Thrush & & & & & & & \\
No & 76 & 69.7 & 29 & 26.6 & 4 & 3.7 & 109 \\
Yes & 9 & 56.3 & 5 & 31.3 & 2 & 12.4 & 16 \\
\hline
\end{tabular}

$(6.7 \%)$, a history of 5 people $(6.4 \%)$, using false teeth as many as 1 person $(11.1 \%)$, having thrush as many as 2 people $(12.4 \%)$.

\section{Discussion}

In research conducted at the health center Posbindu Caringin, almost half of samples at risk of malnutrition, and the rest of the samples are in the normal category. The results in line with the research conducted by Doumit (2014) which found that $27.6 \%$ of the elderly had nutritional status with malnutrition risk categories, and $3.2 \%$ of elderly was malnutrition. The results of this study are in line with the research of Krzyminska et al (2015) with the results of the prevalence of $38.9 \%$ of the elderly at risk of malnutrition, and $7.5 \%$ of the elderly who are malnutrition. This is in line with the results of Wijaya's research (2011) in Yogyakarta with 62 respondents getting the percentage of malnutrition $37.1 \%$.

The problem of malnutrition in the elderly may be caused by several factors. Age is a factor that contributes to the nutritional status of the elderly. Increasing age will cause some changes especially physiological especially digestive function. In this study based on age variables, the highest percentage of malnutrition occurred in the 75-90 year age group. This is because of the older a personage, the more risk of health problems. This result is different from the study conducted by Oktariyani (2012) which found elderly who were at risk of malnutrition with the highest percentage in the age group 75-90 years with a percentage of $56.8 \%$. The results of this study are also in accordance with the research conducted by Kaburagi et al (2011) which found that the percentage of older people at risk of malnutrition was greater in the age group $>75$ years compared to the 65-74 year age group, which was $85.2 \%$. This is also in accordance with Fatmah (2010), where Fatmah explained that with increasing age, the need for carbohydrate and fat nutrients decreases, while the need for protein, vitamins, and minerals increases so that older people who are older can have a greater risk of nutritional problems. In 
Citra Windani Mambang Sari: Elderly Nutrition Status In Caringin Health Center Posbindu

addition, there are physiological changes that make the elderly at risk of malnutrition such as dental conditions, decreased saliva, and also decreased intestinal peristaltic which causes the elderly at risk for malnutrition.

Table 2 illustrates that the incidence of nutritional malls is more prevalent in women. This is similar to research (Jésus et al., 2017) which shows that the incidence of malnutrition is more common among women than men with a ratio of $57.4 \%: 42.6 \%$. The results of this study are in line with Subekti's research (2013) that the highest incidence of malnutrition occurred in women $20.8 \%$. The results of this study are in line with the research conducted by El-Sherbiny et al (2016) which states that the prevalence of malnutrition is higher in women $60.1 \%$ compared to men $46.0 \%$. This result is in line with Hallaj's research (2015) that female elderly is more proportional to malnutrition compared to male elderly at $21.4 \%$. This is due to differences in body composition changes between women and men due to the aging process (Tsousi et al, 2014). Changes in body composition that is in the elderly male muscle mass decreases, while in women the fat mass increases which causes a decrease in Basal Metabolism Rate (BMR). Elderly women need more calories, protein and fat than older men (Fatmah, 2010).

The existence of a disease process in the elderly will affect the absorption of nutrients contained in the food that can affect the nutritional status of the elderly. In addition, the history of the disease also affects the food intake of the elderly, this is due to tighter food arrangements. Some elderly people are too strict in their food choices, for example, because they are told to limit cholesterol, they don't dare eat eggs at all. Most elderly people with diabetes mellitus say they always limit their eating portions.

\section{Conclusion}

Based on the results, it was found that nearly half of the elderly were at risk of malnutrition, and a small percentage had nutritional status in the category of malnutrition. It is expected that nurses who contribute to Posbindu activities can be used as reference material for planning nursing interventions for the elderly who are at risk of malnutrition and even those who are malnutrition. Nurses who are active in Posbindu activities are expected to be able to monitor the condition of the elderly regarding elderly characteristics, which affect the nutritional status of the elderly, especially living with the family. The results of this study are also expected to be used as a basis for learning for nursing institutions in providing nursing care to the nutrition of the elderly.

\section{References}

Dinas Kesehatan Republik Indonesia (2005). Pedoman Pembinaan Kesehatan Usia Lanjut Bagi Petugas Kesehatan II. Jakarta: Depertemen Kesehatan Republik Indonesia.

Doumit, J. (2015). Malnutrition and associated risk factors among elderly living in Lebanese community homes. https://doi. org/10.1108/NFS-09-2014-0084.

El-Sherbiny, N. A., Younis, A., \& Masoud, M. (2016). A comprehensive assessment of the physical, nutritional, and psychological health status of the elderly populace in the Fayoum Governorate (Egypt). Archives of Gerontology and Geriatrics, 66, 119-126. https://doi.org/10.1016/j. archger.2016.06.001.

Fatmah. (2010). Gizi Usia Lanjut. Jakarta: Erlangga.

Hallaj, F. A. (2015). Assessment of the nutritional status of residents in homes for the elderly in Lattakia, Syrian Arab Republic, 753-762.

Jésus, P., Guerchet, M., Pilleron, S., Fayemendy, P., Maxime Mouanga, A., Mbelesso, P., ... Desport, J. C. (2017). Undernutrition and obesity among elderly people living in two cities of developing countries: Prevalence and associated factors in the EDAC study. Clinical Nutrition ESPEN, 21, 40-50. https://doi.org/10.1016/j. clnesp.2017.05.007. 
Citra Windani Mambang Sari: Elderly Nutrition Status In Caringin Health Center Posbindu

Kaburagi, T., Hirasawa, R., Yoshino, H., Odaka, Y., Satomi, M., Nakano, M., ... Sato, K. (2011). Nutritional status is strongly correlated with grip strength and depression in community-living elderly Japanese. Public Health Nutrition, 14(11), 1893-1899. https:// doi.org/10.1017/S1368980011000346.

Kementerian Kesehatan Republik Indonesia. (2012). Pedoman pelayanan gizi lanjut usia. diakses dari http://digilib.poltekkesdepkessby.ac.id/public/POLTEKKESSBY-Books399-Pedomanpelayanangizilanjutusia.PDF.

Krzymińska-Siemaszko, R., Mossakowska, M., Skalska, A., Klich-Rączka, A., Tobis, S., Szybalska, A., ... Wieczorowska-Tobis, K. (2015). Social and economic correlates of malnutrition in Polish elderly population: The results of PolSenior study. Journal of Nutrition, Health and Aging, 19(4), 397-402. https://doi.org/10.1007/s12603-014-0572-7.

Lee, L. C., \& Tsai, A. C. (2012). MiniNutritional Assessment predicts functional decline of elderly Taiwanese: Result of a population-representative sample. British Journal of Nutrition, 107(11), 1707-1713. https://doi.org/10.1017/ S0007114511004880.

Melia, Koesmaningati, H., \& Dewi, ratna sari. (2014). Hubungan Kehilangan Gigi dan Pemakaian Gigi Tiruan Terhadap Status Nutrisi. Departement of Prosthodontics, Faculty of Dentistry, Universitas Indonesia, 5.

Munawirah., Masrul.,Martini, R. D. (2014). Hubungan beberapa faktor risiko dengan malnutrisi pada usia lanjut di Nagari Sijunjung Kecamatan Sijunjung, 6(2012), 324-330.

Oktariyani. (2012). Gambaran status gizi pada lanjut usia di Panti Sosial Tresna Werdha (PSTW) Budi Mulya 01 dan 03 Jakarta Timur. Skripsi Universitas Indonesia.
PH Annalia SW, KA Atchison. (2011). Dental Health Behaviors, Dentition, an Mortality in Elderly: The Leisure World Cohort Study. $J$ Aging Res 2011:1-10.

Prasetyo, W. A., Probosuseno, \& Sumami. (2015). Gangguan depresi berhubungan dengan status gizi pasien psikogeriatri di RSJ DR.Radjiiman Wediodiningrat. Jurnal Gzi dan Dietetik Indonesia, 22-30.

Sari, N. K. (2013). Status gizi, penyakit kronis, dan konsumsi obat terhadap kualitas hidup dimensi kesehatan fisik lansia . Artikel Penelitian Jurusan Ilmu Gizi Fakultas Kedokteran Universitas Diponegoro.

Sari, C. W. M., Parida, U., \& Adiningsih, D. (2018). Sleep Quality of Elderly with Diabetes Melitus. Journal of Nursing Care, 1(2).

Sharma, R. (2012). Relationship between Mini Nutritional Assessment Scores and Socioeconomic Status of the Elderly, 1(2).

Subekti, F. (2013). Analisis Karakteristik Usia Lanjut Berhubungan Dengan Status Gizi Di Posyandu Lansia Dusun Wonogiri Jatirejo Lendah Kulon Progo, Yogykarta, 1-12. Diakses dari: http://digilib.unisayogya. ac.id/328/1.

Tamher, S., \& Noorkasiani. (2009). Kesehatan Usia Lanjut dengan Pendekatan Asuhan Keperawatan. Jakarta: Salemba Medika.

Wijaya, R. (2011). Hubungan Tingkat Ekonomi Dengan Status Gizi Lansia Di Dusun Somokaton Margokaton Seyegan Sleman Yogyakarta, Yogykarta, 1-19. Diakses dari: http://digilib.unisayogya.ac.id/1192/1/.

World Health Organization. (2013). World population ageng 2013. Diakses dari http://www.un.org/en/development/ desa/population/publications/pdf/ageing/ WorldPopulationAgeing2013. 